\title{
Effect of pyroligneous extract of Acacia mearnsii on Tetranychus urticae (Koch, 1836) (Acari, Tetranychidae) and Neoseiulus californicus (McGregor, 1954) (Acari, Phytoseiidae)
}

\author{
Adriana de Castro ${ }^{1}$ \\ Júlia Jantsch Ferla ${ }^{1}$ * \\ Fernanda Majolo ${ }^{2}$ \\ Noeli Juarez Ferla ${ }^{1}$ \\ ${ }^{1}$ Laboratório de Acarologia, Centro Universitário UNIVATES \\ Rua Avelilino Tallini, 171, CEP 95900-000, Lajeado - RS, Brasil \\ ${ }^{2}$ Laboratório de Cultura Celular, Centro Universitário UNIVATES \\ e Laboratório de Biologia Celular e Molecular, Pontifícia Universidade Católica do Rio Grande do Sul \\ Avenida Ipiranga 6690, CEP 90610-000, Porto Alegre - RS, Brasil \\ * Corresponding author \\ julia.ferla@hotmail.com
}

Submetido em 08/08/2014

Aceito para publicação em 25/08/2015

\section{Resumo}

Efeito do extrato pirolenhoso de Acacia mearnsii sobre Tetranychus urticae (Koch, 1836) (Acari: Tetranychidae) e Neoseiulus californicus (McGregor, 1954) (Acari: Phytoseiidae). Este trabalho teve como objetivo determinar o efeito do Extrato Pirolenhoso Decantado (EPD) de acácia-negra sobre Tetranychus urticae (Koch, 1836) (Acari: Tetranychidae) e seu predador, Neoseiulus californicus (McGregor, 1954) (Acari: Phytoseiidae). Seis diferentes concentrações foram testadas, nomeadas, EPD: água 1:600, 1:300, 1:150, 1:75, 1:38 e 1:19 e o tratamento controle com água destilada. Cinco fêmeas de T. urticae e $N$. californicus foram transferidas para arenas, sendo mantidas por um período de oito dias, totalizando cinquenta fêmeas. O EPD causou alta mortalidade para $N$. californicus, enquanto que para $T$. urticae a mortalidade foi significativa em altas concentrações (1:75, 1:38 e 1:19) e em apenas uma concentração intermediária (1:150). Para T. urticae, o EPD provocou baixa mortalidade em baixas concentrações. Para N. californicus, o EPD foi prejudicial em todas concentrações, demonstrando ser prejudicial a este ácaro predador e pouco eficiente no controle de T. urticae.

Palavras-chave: Acacia mearnsii; MIP; Seletividade

\section{Abstract}

This work aimed to determine the effect of decanted pyroligneous extract (DPE) of black Acacia mearnsii on the mites Tetranychus urticae (Koch, 1836) (Acari: Tetranychidae) and Neoseiulus californicus (McGregor, 1954) (Acari: Phytoseiidae). Six different concentrations were tested, namely, DPE: water 1:600, 1:300, 1:150, 1:75, 1:38 and 1:19 and a control treatment with distilled water. Five females of T. urticae and N. californicus were transferred to arenas, totaling 50 females per treatment, for a period of eight days. DPE caused high mortality in $N$. californicus, while in T. urticae, high mortality was observed only at high (1:75, 1:38 and 1:19) 
and intermediate (1:150) concentrations. Notably, DPE was slightly harmful to T. urticae at lower concentrations and harmful to $N$. californicus at all concentrations, indicating that it would have little efficacy in the control of T. urticae.

Key words: Acacia mearnsii; IPM; Selectivity

\section{Introduction}

The smoke resulting from the burning of wood in charcoal production kilns is the main residue of this economic activity, which is released into the atmosphere, acting as a pollutant. Gas emission-reducing processes are usually not used of. However, there is a way to use the smoke and residue produced to prepare a decanted pyroligneous extract (DPE). Accordingly, the smoke is collected and transformed by condensation into a liquid, which has a variety of potential uses in agriculture, such as in eucalyptus (SILVA et al., 2006) and lettuce (MASCARENHAS et al., 2006) crops. In addition, when the extract is produced, the pollution caused by kilns is reduced. According to Miyasaka et al. (2001), crude DPE cannot be used on agricultural crops without undergoing a purification process, mainly to eliminate the tar, which is solubilized immediately after obtaining the product.

The control of pests and disease in plants, including mites, has been done with pesticide application, which can select resistant individuals and may contribute to increasing production costs, and in such case, the products cannot be sold as organics (ALVES et al., 2005). DPE applied in 300- to 600 -fold dilutions is promising in the control of pests and diseases and may be used alone or combined with other plant extracts (MAEKAWA, 2002). From this point of view, the use of DPE could be an alternative in integrated pest management (IPM). Besides the effects reported for DPE, little scientific information is available to support its use and to elucidate its mechanisms of action, especially in relation to the protection of plants against pests and diseases (CAMPOS NETO et al., 1993).

Phytophagous mites are among the groups most studied due to their agricultural importance and because they are found on various plant species of economic importance, causing potential damage to them (MORAES; FLECHTMANN, 2008). Tetranychus urticae is considered one of the main pests that attack various crops in Brazil, including cotton, grapevines, strawberry and others. In general, the damage caused by this species is featured by flecking, discoloration (bronzing) and scorching of leaves. Injury can lead to loss of leaves and even plant death. For their control, large quantities of pesticides are used by farmers (MORAES; FLECHTMANN, 2008).

Phytoseiid mites are predators of spider mites and other small mites and insects on plants. Several members of this family are of great importance in the biological control of spider mites and thrips in greenhouse crop production (ZHANG, 2003). Neoseiulus californicus, a phytoseiid mite commonly found in native plants and some crops in the state of Rio Grande do Sul (FERLA et al., 2007; MARCHETTI; FERLA, 2011), is a selective predator of tetranychid mites (McMURTRY; CROFT, 1997), and it is used commercially as a biological control agent in Brazil and other countries (WATANABE et al., 1994; FERLA et al., 2007; MCMURTRY et al., 2013).

Due to the importance of the mites in agroecosystems, the results obtained in this study may support control strategies that take into account the presence of natural enemies in agricultural environments or that aim to preserve natural enemies using alternative products to control mite pests. The aim of this study was to evaluate in the laboratory the action of DPE on T. urticae and its selectivity, with regard to its predator, $N$. californicus.

\section{Material and Methods}

The study was conducted in the Acarology Laboratory of UNIVATES University Center, Lajeado, state of Rio Grande do Sul, between July and October of 2010. The colonies were started with T. urticae specimens from strawberry plants (Fragaria sp.), from Lajeado County, Rio Grande do Sul State and $N$. californicus from a grapevine of the Merlot variety, from 
Bento Gonçalves County, state of Rio Grande do Sul. Both species were collected in 2010 February and kept in the laboratory on bean leaves (Phaseoulus vulgaris L.).

Neoseiulus californicus colonies were kept in rearing units on a sponge moistened with distilled water in plastic trays with bean leaves infested with T. urticae, covered with cardboard. The units were kept in a climatic chamber at $25 \pm 1{ }^{\circ} \mathrm{C}, 80 \pm 5 \% \mathrm{RH}$ and 12 -h photoperiod. Tetranychus urticae rearing was carried out in similar trays on bean leaves.

DPE of acacia charcoal (Acacia mearnsii De Wild.) obtained from acacia wood burning was stored in a polyethylene drum, covered and allowed to stand for about 100 days to obtain the aqueous phase of the product. It was tested at six concentrations, diluted in water: 1:600; 1:300, 1:150, 1:75, 1:38 and 1:19. Distilled water was used as the control.

In the experiment, we used fertilized females of $N$. californicus and T. urticae, respectively seven and fifteen days old. Tetranychus urticae was kept in arenas of 2.0 $\mathrm{cm}$ in diameter cut into bean leaves, while $N$. californicus fed on T. urticae throughout the experiment.

Arenas were cut and immersed in the DPE solutions and control for approximately eight seconds, withdrawn and dried at room temperature on a paper towel for about one hour. The dried treated arenas were placed on a moistened sponge in a Petri dish of $6.5 \mathrm{~cm}$ in diameter. Five females, apparently healthy, were removed from the rearing colonies and transferred to an arena using a fine paint brush. The experimental design was completely randomized with ten replicates with five mites per replicate.

After the females were transferred to treated circles, the evaluation was daily, where we counted the number of dead females and the eggs laid during a period of eight days. The eggs laid were transferred from the treated arenas to discs also treated to evaluate viability.

The effect of DPE was evaluated as female mortality in the treatment, where mortality was corrected by the control for $N$. californicus and T. urticae. The effect on reproduction was determined only with $N$. californicus (OVERMEER; VANZON, 1982; HASSAN et al., 1985; OVERMEER, 1988; BAKER et al., 1992b). The formula used to calculate total effect was $\mathrm{E}=100 \%-(100 \%$ $\left.-\mathrm{M}_{\mathrm{c}}\right) \times \mathrm{E}_{\mathrm{r}}$, in which $\mathrm{E}=$ total effect, $\mathrm{M}_{\mathrm{c}}=$ corrected mortality $(\mathrm{ABBOTT}, 1925)$ and $\mathrm{E}_{\mathrm{r}}=$ reproduction effect. The reproduction effect was calculated as oviposition of females in each treatment divided by mean control oviposition ( $\left.E_{r}=R_{\text {treatment }} / R_{\text {control }}\right)$. The mean oviposition of females $(\mathrm{R})$ was obtained using the formula: $\mathrm{R}=$ total viable eggs/number of females alive at the end of the test.

The total effect obtained for each product was classified on a scale of 1 to 4 , according to the criteria established by IOBC/WPRS (BAKER et al., 1992a; HASSAN et al., 1994): class 1: $\mathrm{E}<30 \%$ (innocuous, harmless); class 2: $30 \%<\mathrm{E}<79 \%$ (slightly harmful); class 3: $80 \%<\mathrm{E}<99 \%$ (moderately harmful) and class 4: $\mathrm{E}>99 \%$ (harmful).

The results for corrected mortality were subjected to ANOVA and the means compared with the Tukey test at $5 \%$ probability with the Bioestat 5.0 statistics program.

\section{Results and Discussion}

DPE caused high mortality in $N$. californicus $(100 \%)$ at all concentrations studied, while in T. urticae, only 1:150 and higher concentrations caused high mortality (Table 1). At concentrations of 1:600 and 1:300, T. urticae mortality was lower, i.e., 70 and 54\%, respectively. The treatment with low concentration, beyond to show reduced effect on T. urticae mortality. These treatments proved to be sublethal to this phytophagous mite, and their physiologic effect was increased fecundity. According to this work, DPE could eliminate a natural enemy of T. urticae. In the presence of abundant food and absence of natural enemies, there would be an increase in populations of pest species. Thus, these results suggest limiting the use of DPE, but further studies are needed, mainly in the field.

All treatments were shown to be harmful to $N$. californicus. The results obtained demonstrated that DPE at the concentrations used was not selective for $N$. californicus, thus opening the possibility to test this product at lower concentrations. However, we also found that these lower concentrations were innocuous to $T$. urticae, invalidating their use in IPM. 
Comparing the two species evaluated, DPE showed, in general, a greater harmful effect on the predator species than phytophagous species. Against T. urticae, 1:600, 1:300 and 1:75 DPE was slightly harmful, while the other concentrations were considerably harmful, and thus, DPE toxicity increased with concentration, except for 1:75. Against $N$. californicus, DPE was harmful at all concentrations.

By the fifth day, for T. urticae, the highest concentrations caused complete mortality, and at 1:150, just by the seventh day, while the other concentrations did not cause complete mortality. In T. urticae oviposition, the greatest effect was observed at the highest concentration, where the number of eggs laid/day by females was lower than that at other concentrations. During the eight-day observation period, there were small oscillations in the number of eggs at every concentration, with a gradual decrease, except at the 1:75, where there was an increase. At the highest concentration, 1:19, a daily average of 5.5 eggs was observed, compared to 11 eggs per day in the control; in other words, in presence of DPE there was a fifty percent reduction in oviposition.

All predator mites died at the end of the study. During the observation period, the oviposition rate was affected by DPE, where it was lowest at the highest concentration. Regarding the mortality of $N$. californicus, we found that although all predators died at the end of the test, there was variation in the time of complete mortality, i.e., DPE action was more rapid at the higher concentrations. At the lowest concentration (1:600), complete mortality was reached by the eighth day.

The effect of DPE on $N$. californicus oviposition was substantial, where there was complete mortality on the second day at the highest concentration (1:19), with no oviposition observed. Egg number increased with decreasing concentration. Immediately before reaching complete mortality, there was an increase in egg number at the lower concentrations. This increase in oviposition may have been due to the females being in an adverse environment and as a response to enhance fecundity. This phenomenon may be explained by the sublethal action of DPE on biological parameters of this predatory mite, resulting in physiological changes that can alter fertility, reducing it (O'BRIEN et al., 1985) or enhancing it (ATALLAH; NEWSON, 1966; ABLES et al., 1977).

Comparing the effects of DPE on T. urticae and N. californicus oviposition, there was a greater effect on $N$. californicus, because all concentrations showed a lower number of eggs/day. Ferla and Moraes (2006) studied the effects of different insecticides and acaricides on predator mites Euseius concordis (Chant, 1959) and $N$. anonymus (Chant \& Baker, 1965) to evaluate selectivity, and also found that the majority of products were not selective and caused higher toxicity with increasing concentrations.

Alves et al. (2007) observed that DPE caused significant mortality in Brevipalpus phoenicis (Geijskes, 1939) (Acari: Tenuipalpidae) only at concentrations equal to or greater than 1:150. Likewise, in the present study, DPE caused high mortality in T. urticae just at the same high concentrations, higher than that recommended by producers. Therefore, the results obtained with DPE confirm previous studies. DPE has been demonstrated to be harmful to $N$. californicus and only slightly harmful to T. urticae at low concentrations, and therefore, it should not be used in IMP of T. urticae, since it is also harmful at higher concentrations.

\section{Acknowledgments}

The authors thank Dr. Marcos Botton for critical analyses and helpful suggestions to the manuscript, as well as the referees of Biotemas for their constructive comments. Dr. A. Leyva helped with English editing of the manuscript. We also thank to Centro Universitário UNIVATES for the support.

\section{References}

ABBOTT, W. S. A method of computing the effectiveness of an insecticide. Journal of Economic Entomology, Riverside, v. 18, p. 265-267, 1925.

ABLES, J. R.; JONES, S. L.; BEE, M. J. Effect of diflubenzuron on beneficial arthropods associated with cotton [Trichogramma pretiosum, Hippodamia convergens, Chrysopa carnea, predators of cotton pests]. The Southwestern Entomologist, College Station, v. 2, n. 2, p. 66-72, 1977.

ALVES, E. B.; CASARIN, N. F. B.; OMOTO, C. Mecanismos de dispersão de Brevipalpus phoenicis (Geijskes) (Acari: 
Tenuipalpidae) em pomares de citros. Neotropical Entomology, Piracicaba, v. 34, n. 1, p. 89-96, 2005.

ALVES, M.; CAZETTA J. O.; NUNES M. A. Ação de diferentes preparações de extrato pirolenhoso sobre Brevipalpus phoenicis (GEIJSKES). Revista Brasileira Fruticultura, Jaboticabal, v. 29, n. 2, p. 382-385, 2007.

ATALLAH, Y. H.; NEWSOM, L. H. Ecological and nutritional studies on Coleomegilla maculata DeGeer (Coleoptera: Coccinelidae). I. The development of an artificial diet and a laboratory rearing technique. Journal of Economic Entomology, Riverside, v. 59, p. 1173-1178, 1966.

BAKER, F. M.; GROVE, A.; BLÜMEL, S.; CALIS, J.; OOMEN, P. Side-effect test for phytoseiids and their rearing methods. IOBC/ WPRS Bulletin, Zurich, v. 18, n. 3, p. 61-81, 1992a.

BAKER, J.; LEVY, M.; GREWAL, D. An experimental approach to making retail store environmental-decisions. Journal of Retailing, New York, v. 68, n. 4, p. 445-460, 1992 b.

CAMPOS NETO, H. H.; MOURA, E.; PASSOS, H. R.; CINIGLIO NETO, F.; MARICONI, F. A. M.; SCAPARI FILHO, J. A. Combate experimental ao ácaro da leprose Brevipalpus phoenicis (Geijskes, 1939), em citros. Scientia Agrícola, Piracicaba, v. 50, n. 2, p. $267-$ 271, 1993.

FERLA, N. J.; MARCHETTI, M. M.; GONÇALVES, D. Ácaros predadores (Acari) associados à cultura do morango (Fragaria sp., Rosaceae) e plantas próximas no estado do Rio Grande do Sul. Biota Neotropica, Campinas, v. 7, p. 1-8, 2007.

FERLA, N. J.; MORAES, G. J. Seletividade de acaricidas e inseticidas a ácaros predadores (Acari: Phytoseiidae) encontrados em seringueira no centro-oeste do Brasil. Ciência Rural, Santa Maria, v. 36, n. 2, p. 357-362, 2006.

HASSAN, S. A.; ALBERTT, R.; BIGLER, F. Standard method to test the side-effects of pesticides on natural enemies of insects and mites developed by the IOBC/WPRS Working Group "Pesticides and Beneficial Organisms". Bulletin OEPP, Zurich, v. 15, p. $214-$ $255,1985$.

HASSAN, S. A.; BIGLER, F.; BOGENCHÜTZ, H.; BOLLER, E. Results of the sixth joint pesticide testing program of the IOBC/ WPRS-Working Group "Pesticides and beneficial Organisms". Enthomophaga, Paris, v. 39, n. 1, p. 107-119, 1994.
MAEKAWA, K. Curso de produção de carvão, extrato pirolenhoso e seu uso na agricultura. Botucatu: APAN, 2002. s/ paginação.

MARCHETTI, M. M.; FERLA, N. J. Diversidade e flutuação populacional de ácaros (Acari) em amora-preta (Rubus fruticosus, Rosaceae) no estado do Rio Grande do Sul, Brasil. Iheringia, Série Zoológica, Porto Alegre, v. 101, n. 1-2, p. 43-48, 2011.

MASCARENHAS, M. H. T.; LARA, J. F. R.; PURCINO, H. M. A; SIMÕES, J. C.; MOREIRA, D. C.; FACION, C. E. Efeito da utilização do extrato pirolenhoso na produtividade da alface. Revista Brasileira de Horticultura, Goiânia, v. 24, n. 1, p. 31223125, 2006

McMURTRY, J. A.; CROFT, A. B. Life-styles of Phytoseiidae mites and their roles in biological control. Annual Review of Entomology, Palo Alto, v. 42, p. 291-321, 1997.

MIYASAKA, S.; OHKAWARA, T.; NAGAI, K. Técnicas de produção e uso fino de carvão e licor pirolenhoso. In: ENCONTRO DE PROCESSOS DE PROTEÇÃO DE PLANTAS, Controle ecológico de pragas e doenças, I, 2001, Botucatu. Resumos... Botucatu: APAN, 2001. p. 161-176.

MORAES, G. J. de; FleChtMANN, C. H. W. Manual de Acarologia: acarologia básica e ácaros de plantas cultivadas no Brasil. Piracicaba: Halos Editora, 2008. 288 p.

O'BRIEN, S. J.; ROELKE, M. E.; MARKER, I.; NEWMAN, A.; WINKLER, C. A.; MELTZER, D.; COLLY, L.; EVERMANN, J. F.; BUSH, M.; WILDT, D. E. Genetic bases for species vulnerability in the cheetah. Science, New York, v. 227, p. 1428-1434, 1985.

OVERMEER, W. P. J. Laboratory method for testing sideeffects of pesticides on the predacious mites Typhodromus pyri and Amblyseius potentillae (Acari: Phytoseiidae) IOBC/WPRS Bulletin, Zurich, v. 11, n. 4, p. 65-69, 1988.

OVERMEER, W. P. J.; VANZON, A. Q. A standardized method for testing the side-effects of pesticides on the predaceous mite Amblyseius potentillae (Acarina: Phytoseiidae). Entomophaga, Paris, v. 27, n. 4, p. 357-364, 1982.

SILVA, A. S.; ZANETTI, R.; CARVALHO, G. A.; MENDONÇA, L. A. Qualidade de mudas de eucaliptos tratadas com extrato pirolenhoso. Revista Cerne, Lavras, v. 12, n. 1, p. 19-26, 2006.

ZHANG, Z. Mites of greenhouses: identification, biology and control. Oxon: CABI, 2003. 244 p. 